\title{
Estimasi potensi kerugian ekonomi akibat wasting pada balita di indonesia
}

\author{
Brigitte Sarah Renyoet", Hildagardis Meliyani Erista Nai
}

\begin{abstract}
Background: Wasting cases for children under five are currently increasing, the high risk of malnutrition continues to increase so that it has an effect on increasing the prevalence of nutritional problems which results in decreased productivity. Objectives: To estimate the economic potential lost due to wasting in children under five.

Methods: Descriptive research, by processing data from various related agencies which are all in the form of secondary data. Calculate using the Konig (1995) formula and a correction factor from Horton's (1999) study. The research activities are carried out starting July 2018 until September 2018.

Results: Nationally based on the prevalence of wasting in children under five in 2013 amounting to IDR 1.042 billion - IDR 4.687 billion or $0.01 \%-0.06 \%$ of the total GDP of Indonesia.

Conclusion: The prevalence of high wasting problems can increase the potential for economic losses and affect the economy of a country especially in developing countries and one of them is Indonesia.
\end{abstract}

Keywords: low productivity; thin toddlers; lack of food intake; infectious diseases

\begin{abstract}
ABSTRAK
Latar Belakang: Kasus wasting pada balitasaat ini semakin meningkat,tingginya risiko kekurangan gizi terus saja bertambah sehingga memberikan pengaruh terhadap peningkatan prevalensi masalah gizi yang mengakibatkan penurunan produktivitas. Tujuan: Melakukan estimasi potensi ekonomi yang hilang akibat wasting pada balita.

Metode: Penelitian deskriptif, dengan mengolah data dari berbagai instansi terkait yang seluruhnya berupa data sekunder. Menghitung dengan menggunakan rumus Konig (1995) dan faktor koreksi dari penelitian Horton (1999). Kegiatan penelitian dilaksanakan mulai bulan Juli 2018 sampai September 2018.

Hasil: Secara nasional berdasarkan estimasi kerugian ekonomi akibat wasting pada balita tahun 2013 sebesar Rp 1,042 miliar - Rp 4,687 miliar atau 0.01\% - 0.06\% dari total PDB Indonesia.

Simpulan: Angka prevalensi masalah wasting yang tinggi, dapat meningkatkan potensi kerugian ekonomi dan mempengaruhi ekonomi suatu negara khususnya pada negara-negara berkembang dan salah satunya Indonesia.
\end{abstract}

Kata Kunci: produktivitas rendah; balita kurus; asupan makan kurang; penyakit infeksi

\section{PENDAHULUAN}

The United Nations Children's Fund (UNICEF) melaporkan pada tahun 2011 sekitar 52 juta anak berusia dibawah lima tahun mengalami wasting yang disebabkan oleh kekurangan gizi (undernutrition) atau kurangnya asupan makan yang bergizi dan seimbang. ${ }^{1}$ Dalam laporan ini juga diperoleh informasi yang menunjukan bahwa selain masalah stunting atau masalah terhambatnya pertumbuhan anak, Indonesia memiliki kasus wasting yang juga merupakan salah satu kasus terbanyak dengan peringkat keempat dari 88 negara di dunia. Anak berusia dibawah lima tahun atau yang sering dikategorikan dengan sebutan balita, merupakan kelompok umur yang paling rentan untuk terkena masalah gizi.

Balita merupakan kelompok umur yang paling rentan dan sering mengalami kekurangan gizi dan mengakibatkan gizi buruk pada anak. ${ }^{2}$ Terpenuhinya kebutuhan akan gizi merupakan hal yang sangat penting, terutama untuk anak pada awal 1000 Hari Pertama Kehidupan (1000 HPK) dan hal ini perlu ditangani dengan serius. Gangguan status gizi pada awal kehidupan anak akan menyebabkan gangguan pertumbuhan fisik, selain itu dapat mempengaruhi kognitif dan produktivitas ketika anak dewasa dan mulai bekerja. ${ }^{3}$ Kualitas Sumber Daya Manusia (SDM) merupakan salah satu peran penting dalam melaksanakan pembangunan pada sebuah negara, terutama negara berkembang seperti Indonesia. Risiko kematian meningkat tajam karena malnutrisi menjadi lebih parah, selain itu risiko kematian yang tinggi terkait dengan wasting yang parah terlihat pada hasil penelitian yang menunjukkan bahwa seorang anak memiliki risiko sembilan kali lipat lebih tinggi untuk meninggal. ${ }^{4}$

Menurut hasil olah data Riskesdas tahun 2013, prevalensi balita kurus $(6,9 \%)$ dan sangat kurus $(6,7 \%)$ dengan gambaran umum prevalensi wasting mencapai 13,6\% di Indonesia. Kasus wasting (kurus dan sangat

Program Studi Sarjana Gizi, Sekolah Tinggi Ilmu Kesehatan Panti Rapih. Jl. Tantular 401, Pringwulung, Condongcatur, Depok, Sleman, Yogyakarta 55584

*Korespondensi: E-mail: brigitte.sarah@yahoo.com 
kurus) memiliki indikator yaitu BB/TB yang menggambarkan status gizi yang bersifat akut sebagai akibat dari keadaan yang berlangsung dalam waktu pendek, seperti menurunnya nafsu makan karena sakit atau diare, sehingga dalam keadaan demikian berat badan anak akan cepat turun sehingga tidak proporsional lagi dengan tinggi badannya dan anak menjadi kurus. Wasting adalah kondisi dimana seseorang mengalami gizi kurang akut yang ditunjukan dengan berat badan balita yang tidak optimal atau sesuai dengan dengan tinggi badannya atau dapat ditandai dengan nilai $z$-score lebih dari -2SD.

Di India pemborosan akibat masalah gizi 45 sampai dengan 50 juta karena wasting mengakibatkan kerugian ekonomi lebih dari US \$48 miliar dalam produktivitas yang hilang seumur hidup (di mana satu DALY dihargai US $\$ 1.000$ - cara umum untuk menstandardisasi nilai setiap DALY/Disability Adjusted Life Years). ${ }^{5}$ Bank Dunia menghitung bahwa $\$ 7$ miliar per tahun untuk zat gizi mikro, di samping alokasi sumber daya yang ada selama sepuluh tahun ke depan, akan memungkinkan dunia mencapai target World Health Assembly (WHA) global pada tahun 2025 untuk mengurangi stunting, anemia pada wanita, dan meningkatkan pemberian ASI eksklusif, serta mengelola dampak wasting dengan lebih baik. Perkiraan menunjukkan bahwa investasi sebesar $\$ 7$ miliar akan menyelamatkan 3,7 juta nyawa anak, lebih dari 65 juta anak-anak stunting, dan 265 juta perempuan anemia dibandingkan dengan tahun 2015. ${ }^{6}$ Dengan melihat penjelasan dari latar belakang diatas maka, tujuan penelitian ini adalah melakukan estimasi besar potensi kerugian ekonomi akibat wasting pada balita di Indonesia.

\section{BAHAN DAN METODE}

Penelitian ini merupakan penelitian deskritif. Penelitian ini dilakukan dengan mengolah data dari berbagai instansi terkait secara menyeluruh. Kegiatan penelitian dilakukan mulai bulan Agustus 2018 sampai Oktober 2018. Data yang digunakan dalam penelitian ini merupakan data sekunder. Jenis data yang dikumpulkan yaitu: (1) karakteristik balita di Indonesia (umur, jenis kelamin, data status gizi atau Z-score balita, jumlah balita wasting usia 0-59 bulan) yang diperoleh dari Badan Penelitian dan Pengembangan Kesehatan dan data diperoleh dari laporan hasil Riset Kesehatan Dasar (Riskesdas) tahun 20137,8,9; (2) karakteristik penduduk menurut provinsi (jumlah kelahiran, jenis kelamin, dan kelompok umur) tahun 2013 yang bersumber dari Badan Pusat Statistik (BPS) ${ }^{10,11}$ dan Kementerian Kesehatan RI (Kemenkes); dan (3) data upah/gaji tenaga kerja (data upah/pendapatan bersih pekerja menurut provinsi dan lapangan pekerjaan utama) dari Badan Pusat Statistik
(BPS) tahun 2013. Data yang diperoleh selanjutnya akan diolah dengan menggunakan program Microsoft Excel. Tahapan rumus perhitungan yang digunakan untuk menghitung besar potensi kerugian ekonomi karena masalah wasting pada balita dengan menggunakan rumus konig ${ }^{12}$ dan faktor koreksi. ${ }^{13}$

Nilai ekonomi anak saat mulai bekerja dapat dihitung dengan menggunakan rumus Konig ini:

$$
\begin{gathered}
\mathrm{FV}_{[\mathrm{r}, \mathrm{t}]}=\mathrm{P}_{0}(1+ \\
\mathrm{r})^{\mathrm{t}}
\end{gathered}
$$

Keterangan:

$\mathrm{FV}_{[\mathrm{r}, \mathrm{t}]} \quad=$ Pendapatan di usia produktif (15-64th)

$\mathrm{P}_{0} \quad=$ Upah/gaji 2013

$\mathrm{r}=$ Discount rate

$\mathrm{t}=$ Tahun kehidupan yang produktif

Besarnya nilai ekonomi sampai anak masuk masa pensiun dihitung dengan menggunakan rumus ini:

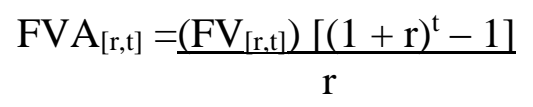

Keterangan:

$\mathrm{FVA}_{[\mathrm{r}, \mathrm{t}]}=$ Nilai ekonomi sampai anak masuk masa pensiun

$\mathrm{FV}_{[\mathrm{r}, \mathrm{t}]}=$ Pendapatan diusia produktif $(\mathrm{e}, \mathrm{g}$ $15^{\text {th }}$ year)

\section{$\mathrm{r}=$ Discount rate}

$\mathrm{t}=$ Tahun kehidupan yang produktif

Besarnya potensi ekonomi anak saat berusia 0 tahun dapat dihitung dengan menggunakan rumus ini:

$$
\left.\mathrm{PV}_{[0]}=\frac{\mathrm{FVA}}{(1+\mathrm{r}, \mathrm{r}]}\right)^{\mathrm{t}}
$$

Keterangan:

$\mathrm{PV}_{[0]}=$ Potensi ekonomi anak saat berusia 0 tahun

$\mathrm{FVA}_{[\mathrm{r}, \mathrm{t}]}=$ Nilai ekonomi sampai anak masuk masa pensiun

$\mathrm{r}=$ Discount rate (suku bunga)

$\mathrm{t}=$ Tahun kehidupan yang produktif

Besarnya biaya produktivitas yang hilang akibat wasting dihitung dengan menggunakan rumus berikut ini:

$$
\mathrm{P}_{\mathrm{PEM}}=\operatorname{Prev} \times \Sigma \mathrm{BL} \times \mathrm{PV}_{[0]}
$$

\section{Keterangan:}

$\mathrm{P}_{\mathrm{PEM}}=$ Potensi ekonomi yang hilang akibat wasting

Prev = Prevalensi wasting

$\Sigma \mathrm{BL}=$ Jumlah kelahiran

$\mathrm{PV}_{[0]}=$ Potensi ekonomi anak saat berusia 0 tahun

Potensi kerugian ekonomi akibat wasting setelah dikoreksi dengan menggunakan faktor pengoreksi. ${ }^{13}$ dapat menggunakan rumus berikut:

$$
\mathrm{P}=\mathrm{f}_{\text {(cor) }} \times \operatorname{Prev}^{\mathrm{x}} \Sigma \mathrm{BL} \times \mathrm{PV}_{[0]}
$$


Keterangan:

$\mathrm{P} \quad=$ Besarnya kerugian ekonomi yang telah dikoreksi

$\mathrm{f}_{\text {(cor) }} \quad=$ Faktor koreksi $(2 \%$ dan 9\%)

Prev = Prevalensi underweight

$\Sigma \mathrm{BL}=$ Jumlah kelahiran

$\mathrm{PV}_{[0]}=$ Potensi ekonomi anak saat berusia 0 tahun

Penelitian ini menggunakan beberapa asumsi. Asumsiasumsi ini digunakan agar hasil penelitian dapat diterima secara umum. Asumsi yang digunakan dalam penelitian yaitu: (1) balita underweight akan mengalami penurunan produktivitas sebesar 2\% - 9\% menurut Horton (1999); (2) Gaji/upah yang diterima pada semua sektor lapangan usaha sama; (3) Data yang digunakan memiliki karakteristik subjek yang sama; (4) Discount rate yang digunakan $5 \%$.

\section{HASIL}

\section{Prevalensi Masalah Wasting pada Balita di Indonesia}

Tabel 1 adalah prevalensi dari masalah wasting di 33 provinsi di Indonesia dari hasil olah data sekunder Riskesdas tahun 2013 untuk masalah wasting.

Lima provinsi yang memiliki prevalensi wasting tertinggi yaitu Provinsi Kalimantan Barat, Riau, Papua Barat, Sumatera Utara, dan Nusa Tenggara Timur.

\section{Estimasi Potensi Kerugian Ekonomi Akibat Masalah Wasting pada Balita di Indonesia}

Tabel 2 adalah estimasi kehilangan potensi ekonomi akibat masalah wasting menggunakan rumus dan faktor koreksi yang sama dengan perhitungan kerugian ekonomi karena underweight.

Besar rata-rata potensi ekonomi yang hilang akibat masalah wasting pada balita di 32 provinsi di Indonesia ketika dewasa dan mengalami kehilangan produktivitas sebesar $2 \%$ adalah $\mathrm{Rp} 32$ miliar, sedangkan jika penurunan produktivitas sebesar $9 \%$ adalah Rp 142 miliar.

\section{PEMBAHASAN}

\section{Prevalensi Masalah Wasting pada Balita di Indonesia}

Wasting mengakibatkan terganggunya pertumbuhan fisik dan kognitif anak, bahkan lebih buruknya wasting akan berdampak terhadap kematian balita. $^{14,15}$ Menurut Anindya, Sumber Daya Manusia (SDM) adalah Indeks Pembangunan Manusia (IPM) atau Human Development Indeks (HDI). HDI memiliki tiga faktor utama penentu yaitu, pendidikan, kesehatan dan ekonomi. Ketiga faktor tersebut berkaitan erat dengan status gizi masyarakat, karena anak yang memperoleh makanan adekuat sejak kandungan dan memiliki status gizi yang baik akan tumbuh dan berkembang dengan optimal sesuai dengan usianya serta memiliki usia harapan hidup yang baik karena kesehatannya yang baik. Salah satu faktor yang menyebabkan balita mengalami wasting (kurus) adalah kondisi lingkungan (sanitasi dan hygiene), kemiskinan dan pola asuh (makanan, kebersihan, serta berbagai faktor lainnya). Semua ini dapat mengakibatkan balita sakit atau diare jika tidak segera diatasi dengan pengobatan dan pemberian makanan yang bergizi. Selain itu, balita akan mengalami kekurangan berat badan, lemas, sistem imunitas berkurang sampai dengan kondisi kronis dan berakhir pada kematian balita.

Tabel 1 Prevalensi Balita Wasting di Indonesia Tahun 2013

\begin{tabular}{clcc}
\hline No. & \multicolumn{1}{c}{ Provinsi } & $\begin{array}{c}\text { Prevalensi } \\
\text { Wasting } \\
(\boldsymbol{\%}) *\end{array}$ & $\begin{array}{c}\text { Jumlah } \\
\text { Balita } \\
\text { Wasting }\end{array}$ \\
\hline 1. & Aceh & 16,0 & 89.544 \\
2. & Sumatera Utara & 17,1 & 56.670 \\
3. & Sumatera Barat & 14,9 & 18.957 \\
4. & Riau & 18,0 & 216.754 \\
5. & Jambi & 15,7 & 28.386 \\
6. & Sumatera Selatan & 14,4 & 38.711 \\
7. & Bengkulu & 15,4 & 143.329 \\
8. & Lampung & 13,9 & 15.103 \\
9. & Kep. Bangka Belitung & 10,9 & 35.251 \\
10. & Kepulauan Riau & 10,6 & 458.303 \\
11. & DKI Jakarta & 11,5 & 319.405 \\
12. & Jawa Barat & 11,1 & 330.727 \\
13. & Jawa Tengah & 11,8 & 57.969 \\
14. & D.I. Yogyakarta & 7,6 & 31.044 \\
15. & Jawa Timur & 11,5 & 28.020 \\
16. & Banten & 13,7 & 55.610 \\
17. & Bali & 8,5 & 18.257 \\
18. & Nusa Tenggara Barat & 14,2 & 113.874 \\
19. & Nusa Tenggara Timur & 16,8 & 32.732 \\
20. & Kalimantan Barat & 19,3 & 26.149 \\
21. & Kalimantan Tengah & 12,9 & 65.609 \\
22. & Kalimantan Selatan & 13,6 & 84.200 \\
23. & Kalimantan Timur & 13,7 & 45.037 \\
24. & Sulawesi Utara & 10,9 & 10.069 \\
25. & Sulawesi Tengah & 10,3 & 72.034 \\
26. & Sulawesi Selatan & 12,1 & 17.105 \\
27. & Sulawesi Tenggara & 13,5 & 112.299 \\
28. & Gorontalo & 14,4 & 42.395 \\
29. & Sulawesi Barat & 11,9 & 34.987 \\
30. & Maluku & 16,6 & 34.586 \\
31. & Maluku Utara & 13,6 & 109.275 \\
32. & Papua Barat & 17,1 & 93.516 \\
33. & Papua & 15,2 & 238.634 \\
\hline & Indonesia & $\mathbf{3 . 2 5 9 . 7 2 1}$ \\
\hline
\end{tabular}

*Hasil olah data mikro (Riskesdas 2013) oleh peneliti; Sumber: BPS 2013, Badan Penelitian dan Pengembangan Kesehatan 2013 
Tabel 2 Estimasi Potensi Kerugian Ekonomi Karena Wasting

\begin{tabular}{|c|c|c|c|c|c|}
\hline \multirow[b]{2}{*}{ No. } & \multirow[b]{2}{*}{ Provinsi } & \multicolumn{2}{|c|}{ Potensi Kerugian Ekonomi } & \multicolumn{2}{|c|}{ \%PDRB } \\
\hline & & $2 \%$ (miliar rupiah) & 9\% (miliar rupiah) & $2 \%$ & $9 \%$ \\
\hline 1. & Aceh & 18 & 80 & 0,02 & 0,09 \\
\hline 2. & Sumatera Utara & 21 & 92 & 0,01 & 0,02 \\
\hline 3. & Sumatera Barat & 19 & 86 & 0,02 & 0,07 \\
\hline 4. & Riau & 32 & 142 & 0,01 & 0,04 \\
\hline 5. & Jambi & 32 & 143 & 0,04 & 0,19 \\
\hline 6. & Sumatera Selatan & 89 & 400 & 0,05 & 0,22 \\
\hline 7. & Bengkulu & 10 & 44 & 0,04 & 0,16 \\
\hline 8 & Lampung & 26 & 117 & 0,02 & 0,07 \\
\hline 9 & Kep. Bangka Belitung & 2 & 10 & 0,01 & 0,03 \\
\hline 10 & Kepulauan Riau & 1 & 4 & 0,00 & 0,00 \\
\hline 11 & DKI Jakarta & 8 & 37 & 0,00 & 0,00 \\
\hline 12 & Jawa Barat & 112 & 504 & 0,01 & 0,05 \\
\hline 13 & Jawa Tengah & 142 & 638 & 0,03 & 0,11 \\
\hline 14 & D.I. Yogyakarta & 7 & 30 & 0,01 & 0,05 \\
\hline 15 & Jawa Timur & 109 & 490 & 0,01 & 0,04 \\
\hline 16 & Banten & 10 & 45 & 0,00 & 0,02 \\
\hline 17 & Bali & 19 & 84 & 0,02 & 0,09 \\
\hline 18 & Nusa Tenggara Barat & 23 & 105 & 0,04 & 0,19 \\
\hline 19 & Nusa Tenggara Timur & 20 & 88 & 0,05 & 0,22 \\
\hline 20 & Kalimantan Barat & 43 & 195 & 0,05 & 0,23 \\
\hline 21 & Kalimantan Tengah & 7 & 33 & 0,01 & 0,05 \\
\hline 22 & Kalimantan Selatan & 7 & 30 & 0,01 & 0,04 \\
\hline 23 & Kalimantan Timur & 67 & 300 & 0,02 & 0,11 \\
\hline 24 & Sulawesi Utara & 12 & 54 & 0,02 & 0,10 \\
\hline 25 & Sulawesi Tengah & 1 & 6 & 0,00 & 0,01 \\
\hline 26 & Sulawesi Selatan & 75 & 339 & 0,04 & 0,18 \\
\hline 27 & Sulawesi Tenggara & 22 & 100 & 0,05 & 0,25 \\
\hline 28 & Gorontalo & 8 & 35 & 0,07 & 0,30 \\
\hline 29 & Sulawesi Barat & 39 & 178 & 0,24 & 1,10 \\
\hline 30 & Maluku & 7 & 31 & 0,05 & 0,24 \\
\hline 31 & Maluku Utara & 50 & 225 & 0,65 & 2,92 \\
\hline 32 & Papua Barat & - & - & - & - \\
\hline 33 & Papua & 4 & 17 & 0,00 & 0,02 \\
\hline & Indonesia & 1.042 & 4.687 & $\mathbf{0 , 0 1}$ & 0,06 \\
\hline
\end{tabular}

Keterangan: PDRB atas dasar harga berlaku tanpa migas; Sumber: Data sekunder (olah) 2013

Tingginya prevalensi balita yang mengalami wasting di beberapa provinsi di Indonesia menunjukan bahwa masih banyak tugas dan tanggungjawab pemerintah dalam menangani masalah kesehatan dan gizi terutama untuk kelompok rawan ini, yaitu balita. Secara umum dapat dikatakan bahwa peningkatan ekonomi sebagai dampak dari menurunnya masalah gizi kurang dapat dilihat dari dua sisi, yaitu pertama berkurangnya biaya yang berkaitan dengan kesakitan dan kematian, serta di sisi lain akan meningkatkan produktivitas. Kelaparan dan gizi buruk banyak terjadi di negara berkembang dan negara-negara miskin di dunia, persoalan gizi ini terjadi karena kekurangan asupan makanan yang menyebabkan terjadinya defisiensi gizi seperti kekurangan energi protein, anemia, defisiensi iodium, dan kekurangan mikronutrient lain. ${ }^{16}$ Menurut World Health Organization, anak penderita gizi buruk berisiko kematian 5-20 kali lebih besar daripada anak dengan status gizi baik.
Malnutrisi bertanggung jawab baik secara langsung maupun tidak langsung terhadap 60\% kematian pada balita dan lebih dari dua pertiga kematian justru terjadi pada anak usia kurang dari satu tahun. ${ }^{17}$ Negara berkembang membutuhkan sumber daya manusia yang berkualitas dan memiliki nilai produktif yang tinggi dan pencapaian pembangunan manusia ini diukur dengan Indeks Pembangunan Manusia (IPM). Menurut laporan pembangunan manusia Indonesia tahun 2016, IPM Indonesia berada di peringkat ke 113 dari 188 negara. IPM Indonesia masih tergolong rendah jika dilihat dari jumlah urutannya dengan negara-negara lain didunia, hal ini sangat dipengaruhi oleh status kesehatan dan status gizi penduduk di Indonesia. Salah satu alasannya karena masih tingginya angka kematian bayi dan angka kematian ibu di Indonesia. Lebih dari separuh kematian bayi dan balita disebabkan karena status gizi balita yang buruk. Kemiskinan dan kurang gizi memiliki hubungan satu dengan yang lainnya, oleh karena itu meningkatkan 
status gizi suatu masyarakat erat kaitannya dengan upaya peningkatan ekonomi. Beberapa penelitian di banyak negara menunjukkan bahwa proporsi bayi dengan BBLR berkurang seiring dengan peningkatan pendapatan nasional suatu negara.

\section{Estimasi Potensi Kerugian Ekonomi Akibat Masalah Wasting pada Balita di Indonesia}

Rata-rata potensi ekonomi yang hilang pada 32 provinsi di Indonesia sekitar Rp 32 miliar - Rp 142 miliar, jika nilai ini dilihat dalam persentase terhadap Produk Domesti Regional Bruto (PDRB) maka besar potensi ekonomi yang hilang akibat penurunan produktivitas $2 \%$ dan $9 \%$ sekitar $0,05 \%$ - 0,2\% dari rata-rata PDRB provinsi-provinsi di Indonesia. Rentang tertinggi kehilangan potensi ekonomi karena wasting sebesar Rp 142 miliar - Rp 638 miliar di Provinsi Jawa Tengah atau persentase penurunan produktivitas terhadap PDRB provinsinya sekitar $0,03 \%$ pada penurunan produktivitas $2 \%$ dan $0,1 \%$ penurunan produktivitas $9 \%$. Sedangkan rentang terendah sekitar Rp 1 miliar - Rp 4 miliar di Provinsi Kepulauan Riau pada penurunan produktivitas $2 \%$ dan $9 \%$ atau $0,001 \%$ dan $0,004 \%$ terhadap PDRB provinsinya. Besar potensi ekonomi yang hilang akibat masalah wasting pada balita secara nasional, ketika dewasa dan mengalami kehilangan produktivitas sebesar 2\% adalah Rp 1.042 miliar, sedangkan jika penurunan produktivitas sebesar 9\% adalah $\mathrm{Rp} 4.687$ miliar. Jika nilai-nilai ini dilihat dalam persentase terhadap PDB Indonesia maka besarnya potensi ekonomi yang hilang akibat penurunan produktivitas $2 \%$ secara nasional adalah $0,01 \%$ dan pada penurunan produktivitas sebesar $9 \%$ mencapai 0,06\% dari total PDB Indonesia.

Secara nasional, dapat dikatakan bahwa besar potensi ekonomi yang hilang akibat produktivitas yang rendah karena adanya wasting pada balita sekitar Rp 1.042 miliar - Rp 4.687 miliar atau 0,01\% - 0,06\% dari total PDB Indonesia. Sama halnya dengan kerugian ekonomi akibat underweight, hasil perhitungan potensi kerugian akibat wasting ini juga bukan merupakan total hasil potensi kerugian ekonomi secara keseluruhan dari akibat yang muncul karena masalah wasting. Masalah gizi ini terjadi karena kondisi kesehatan yang terganggu seperti diare, kehilangan nafsu makan karena sakit atau alasan tertentu. Jika hal tersebut berlangsung terus menerus masalah gizi ini dapat mengakibatkan kematian dini. Oleh karena keterbatasan data, maka hasil perhitungan kerugian ini bukan merupakan total hasil dari potensi kerugian ekonomi karena masalah wasting dan dampak lain yang ditimbulkan karena masalah gizi ini.

Menurut African Union Commission kekurangan gizi menghabiskan hampir US \$ 600 juta pada tahun 2012, setara dengan lebih dari $10 \%$ dari PDB tahun itu. Faktor yang berhubungan nyata terhadap wasted adalah perilaku higiene, pemanfaatan posyandu, dan imunisasi lengkap. Selain itu jika permasalahan kurang gizi tidak segera diatasi, maka akan berdampak pada kematian anak, penurunan kemampuan belajar, kemampuan kognitif, anggaran pencegahan dan perawatan yang meningkat dan penurunan produktivitas kerja. ${ }^{18}$

\section{SIMPULAN}

Wasting pada balita berdampak pada timbulnya potensi kerugian ekonomi. Secara nasional berdasarkan prevalensi wastingpada anak balita tahun 2013 sebesar Rp 1.042 miliar - Rp 4.687 miliar atau 0,01\% - 0,06\% dari total PDB Indonesia. Besar rata-rata potensi ekonomi yang hilang di 32 provinsi yang ada di Indonesia sekitar Rp 32 miliar - Rp 142 miliar, jika nilai ini dilihat dalam persentase terhadap PDRB maka besar potensi ekonomi yang hilang akibat penurunan produktivitas $2 \%$ dan $9 \%$ sekitar $0,05 \%$ - 0,2\% dari rata-rata PDRB provinsi-provinsi di Indonesia. Rentang tertinggi kehilangan potensi ekonomi karena wasting sebesar Rp 142 miliar - Rp 638 miliar di Provinsi Jawa Tengah atau persentase penurunan produktivitas terhadap PDRB provinsinya sekitar $0,03 \%$ pada penurunan produktivitas $2 \%$ dan $0,1 \%$ penurunan produktivitas $9 \%$. Rentang terendah sekitar Rp 1 miliar - Rp 4 miliar berada di Provinsi Kepulauan Riau pada penurunan produktivitas $2 \%$ dan $9 \%$ atau $0,01 \%$ dan $0,004 \%$ terhadap PDRB provinsinya. Keterbatasan penelitian ini adalah kerugian ekonomi yang dimaksud adalah kerugian ekonomi yang disebabkan oleh rendahnya produktivitas akibat masalah wasting, sehingga secara tidak langsung menyebabkan masalah ekonomi bagi pemerintah.

\section{UCAPAN TERIMA KASIH}

Penulis menyampaikan terima kasih kepada Kopertis Wilayah V Yogyakarta atas dana penelitian yang diberikan kepada penulis. Badan Penelitian dan Pengembangan Kesehatan, Badan Pusat Statistik, dan Kementerian Kesehatan RI yang telah menyediakan data penelitian.

\section{SARAN}

Perlu dilakukan peningkatan ekonomi di Indonesia untuk menurunkan dampak dari masalah gizi kurang, karena masih banyak terutama masalah gizi kurang terutama pada kelompok rawan, yaitu balita.

\section{DAFTAR PUSTAKA}

1. United Nations Children's Fund. Improving Child Nutrition: The Achievable Imperative for Global 
Progress. New York: Oxford University Press; 2013.

2. Notoatmodjo S. Promosi Kesehatan : Teori dan Aplikasidan. Jakarta: PT Rineka Cipta; 2010.

3. Supariasa IDN, Bakri B, Fajar I. Penilaian Status Gizi. Jakarta: Buku Kedokteran EGC; 2001.

4. Black RE, Victora CG, Walker SP, Bhutta ZA, Christian P, de Onis M, et al. Maternal and child undernutrition and overweight in lowincome and middle income countries. Lancet 2013; 382(9890): 427-451.

5. Freijer K, Tan SS, Koopmanschap MA, Meijers JMM, Halfens RJG, Nuijten MJC. The economic costs of disease related malnutrition. Clinical Nutrition. 2013; 32(1): 136-141.

6. Shekar M, Kakiatek J, D'Alimonte, M, Walters D, Rogers H, Dayton EJ, et al. Investing In Nutrition: The Foundation For Development and Investment Framework To Reach The Global Nutrition Targets. USA: Washington; 2015.

7. Badan Penelitian dan Pengembangan Kesehatan. Laporan Hasil Riset Kesehatan Dasar Indonesia Tahun 2013. Jakarta: Kementerian Kesehatan Republik Indonesia; 2013

8. Badan Penelitian dan Pengembangan Kesehatan. Pokok-Pokok Hasil Riskesdas Provinsi Tahun 2013. Jakarta: Kementerian Kesehatan Republik Indonesia; 2013.

9. Badan Penelitian dan Pengembangan Kesehatan. Riskesdas 2013 Dalam Angka. Jakarta: Kementerian Kesehatan Republik Indonesia; 2013.
10. Badan Pusat Statistik. Keadaan Pekerja Di Indonesia November 2013. Jakarta: Badan Pusat Statistik Republik Indonesia; 2013.

11. Badan Pusat Statistik. Laporan Bulanan Data Sosial Ekonomi. Jakarta: Badan Pusat Statistik Republik Indonesia; 2014.

12. Aries M, Martianto D. Estimasi kerugian ekonomi akibat status gizi buruk dan biaya penanggulangannya pada balita di berbagai provinsi di Indonesia. Jurnal Gizi dan Pangan. 2006; 1(2): 26-33.

13. Horton S. Opportunities For Investments In Nutrition In Low-Income Asia. Asian Development Review. 1999; 17: 246-273.

14. Soendjojo RD, Sritje H, Mien S. Menstimulasi Anak Usia 0-1 Tahun. Jakarta: PT. Elexmedia Komputindo; 2000.

15. Departemen Kesehatan Republik Indonesia. Pemantauan Pertumbuhan Balita. Jakarta: Direktorat Gizi Departemen Kesehatan Republik Indonesia; 2002.

16. Atmarita. Nutrition Problems in Indonesia. 2005; 28(2):43-55.

17. Amsalu S, Tigabu Z. Risk Factors For Severe Acute Malnutrition In Children Under The Age Of Five: A Case-Control Study. Ethiopian Journal of Health Development. 2008; 22(1): 121-5.

18. Ulfani DH, Martianto D, Baliwati YF. FaktorFaktor Sosial Ekonomi Dan Kesehatan Masyarakat KaitannyaDengan Masalah Gizi Underweight, Stunted, Dan Wasted Di Indonesia: Pendekatan Ekologi Gizi. Jurnal Gizi dan Pangan. 2011; 6(1): $59-65$. 